\title{
Brexit's Long-Run Effects on the U.K. Economy
}

\begin{abstract}
What will be the long-run economic effects of the United Kingdom's decision to leave the European Union-informally known as Brexit? Compared with remaining in the European Union, there will inevitably be higher trade costs with the rest of Europe, which accounts for about half of all U.K. trade. This will mean lower trade and foreign investment, and thus lower average U.K. incomes. These trade costs will arise from some combination of tariff and nontariff barriers, and will be larger if there is a "hard Brexit," whereby the United Kingdom would leave the Single Market and trade under World Trade Organization rules, rather than a "soft Brexit" option of staying in the Single Market (like Norway). Calculations using a standard multicountry, multisector, computable general equilibrium model show welfare losses of 1.3 to 2.6 percent, but dynamic models that incorporate productivity effects suggest that these could rise to 6.3 to 9.5 percent. Brexit's supposed benefits-such as lower immigration, better regulations, and more trade deals with non-EU countrieswould do little or nothing to offset these losses. It seems unlikely that voters were fully aware of the magnitude of these costs at the time of the vote.
\end{abstract}

n the referendum held on June 23, 2016, the United Kingdom voted to leave the European Union by a margin of 51.9 percent to 48.1 percent. Although opinion polls had been close, the betting markets had predicted a victory for the campaign to remain, so markets were caught by surprise. Sterling collapsed, from $\$ 1.50$ to $\$ 1.33$, within hours after the early results were announced.

What are likely to be Brexit's medium to long-run effects on the U.K. economy?

There are many elements in making such an assessment, and many unknowns. Here, I focus on Brexit's impact via the likely changes in trade patterns, which is the most obvious aspect that will change. I also look at foreign direct investment (FDI), immigration, and regulations. I mainly 
focus on average effects, but also say some words on the distribution of the costs and benefits.

I abstract from short-run effects preceding Brexit actually occurring-it is certainly likely that there will be some costs of policy uncertainty (Bloom 2014; Handley and Limão 2015). Nor do I look at the period from the initial post-Brexit transitional phase to the new steady state. To do this would require a more formal macroeconometric model incorporating adjustment costs (Armstrong and Portes 2016). These aspects are obviously important and would increase the losses discussed here, but my aim is to keep things as simple as possible.

The bottom line is straightforward: Under all plausible scenarios, Brexit will make Britain poorer compared with remaining in the European Union. This is because the United Kingdom will have higher trade costs with its closest neighbors in Europe (which account for about half of all U.K. trade), and this will reduce its trade and therefore welfare. The magnitude of these losses will outweigh the modest benefits of lower net fiscal transfers to the EU budget.

Brexit's overall net cost will depend crucially on Britain's final trading arrangement with Europe. A "soft Brexit," whereby the United Kingdom continues to have close integration with the European Single Market (as does Norway), would have the lowest cost. ${ }^{1}$ A "hard Brexit," whereby Britain's access to EU markets is much lower than now (on par with that of the United States or Japan, for example), would have much more damaging effects. Given that a majority of U.K. voters seem to have acted against their economic self-interest, I end with some speculations about why the campaign to leave prevailed.

\section{Trade}

Membership in the European Union has reduced trade costs between the United Kingdom and the rest of Europe. Most obviously, there is a customs union between EU members, which means that all tariff barriers have been removed within the EU, allowing for free trade in goods and services.

But equally important in reducing trade costs has been the reduction of nontariff barriers resulting from the European Union's continuing efforts to create a Single Market within Europe. Nontariff barriers include a wide range of measures that raise the costs of trade—-such as border controls,

1. The European Single Market is the name given to the integrated European economy created by removing economic barriers between EU members. 
rules-of-origin checks, cross-country differences in regulations over things like product standards and safety, and threats of antidumping.

These reductions in trade barriers have increased trade between the United Kingdom and the other members of the European Union. Before the United Kingdom joined the European Economic Community (EEC) in 1973, about one-third of U.K. trade was with the EEC. In 2014, the 27 other EU members accounted for 45 percent of U.K. exports, and 53 percent of imports (Office for National Statistics 2015).

This higher trade benefits U.K. consumers through lower prices and access to better goods and services. At the same time, workers and businesses benefit from new export opportunities that lead to higher sales and profits, and allow the United Kingdom to specialize in those industries where it has a comparative advantage. Through these channels, increased trade raises output, incomes, and living standards in the United Kingdom.

These standard "static" effects of trade have been understood for many centuries, but in recent decades, studies of trade have also revealed trade's positive effects on well-being via other routes, such as higher productivity and innovation.

\section{I.A. Trade's Static Effects}

Swati Dhingra and others (2016a) use a modern quantitative trade model of the global economy to estimate Brexit's effects on trade and living standards, building on the work of Arnaud Costinot and Andrés Rodríguez-Clare (2014). This model incorporates the channels through which trade affects consumers, firms, and workers, and provides a map from trade data to welfare. The model provides numbers for how much real incomes change under different trade policies, using readily available data on trade volumes and potential trade barriers. We use the most recent data from the World InputOutput Database, which divides the world into 35 sectors and 31 regions. ${ }^{2}$ It allows for trade in both intermediate inputs and final output in both goods and services. It is a structural computable general equilibrium model that is consistent with the gravity relationship (geographically closer countries trade more with each other). The model takes into account the effects of Brexit on U.K. trade with the EU, and U.K. trade with the rest of the world.

To forecast the consequences of the United Kingdom leaving the European Union, we must make assumptions about how trade costs will change

2. Throughout this paper, references to "we," as in this sentence, refer to the work of the "Brexit team" at the London School of Economics' Centre for Economic Performance; see the acknowledgments at the end of the paper. 
following Brexit. It is not known exactly how the United Kingdom's relations with the European Union will change following Brexit. To tackle this, we analyze two scenarios: an optimistic, "soft Brexit" scenario, in which the increase in trade costs between the United Kingdom and the European Union is small; and a pessimistic, "hard Brexit" scenario with a larger rise in trade costs.

The soft Brexit scenario assumes that the United Kingdom's trade relations with the European Union will become similar to those currently enjoyed by Norway. As a member of the European Economic Area (EEA), Norway has a free trade agreement with the European Union, which means that there are no tariffs on trade between the two. Norway is also a member of the European Single Market, and thus it has adopted policies and regulations designed to reduce nontariff barriers within the Single Market.

However, Norway is not a member of the European Union's Customs Union, so it faces some nontariff barriers that do not apply to EU members, such as rules-of-origin requirements and antidumping duties. Nauro Campos, Fabrizio Coricelli, and Luigi Moretti (2015) find that Norway's productivity growth has been harmed by not fully participating in the European Union's market integration programs.

In the soft Brexit scenario, we assume that the United Kingdom and the European Union will continue to enjoy deep access to the Single Marketlike Norway-and that Brexit will not lead to any change in tariff barriers. In the hard Brexit scenario, we assume that trade between the United Kingdom and the European Union will be governed by World Trade Organization (WTO) rules. This implies larger increases in trade costs than the soft Brexit scenario, because most-favored-nation tariffs will be imposed on trade between the United Kingdom and the European Union, and because the WTO will make less progress on reducing nontariff barriers than the European Union. ${ }^{3}$

The European Union has always insisted that all countries with deep access to the Single Market must accept the free movement of labor. Even Switzerland, which has access to the Single Market in goods (but not in services, like banking), must abide by this. Because immigration controls were a major issue in the U.K. referendum, at the time of writing, a hard Brexit looks more likely.

3. Under WTO rules, each member must grant the same market access-including charging the same tariffs - to all other members as the most favored nation. The only exceptions to this principle are that countries can choose to enter into free trade agreements, such as the European Union or the European Free Trade Association, and can give preferential market access to developing countries. 
The increases in trade costs between the United Kingdom and the European Union following Brexit can be divided into three categories: (i) higher tariffs on imports; (ii) higher nontariff barriers to trade, arising from different regulations, border controls, and the like; and (iii) the lower likelihood of the United Kingdom participating in future EU integration efforts, such as the continued reduction of nontariff barriers.

Regarding nontariff barriers, in the soft Brexit scenario we assume that trade between the United Kingdom and the European Union is subject to one-quarter of the reducible nontariff barriers that are observed in trade between the United States and the European Union. In the hard Brexit scenario, we assume a larger increase of three-quarters of reducible nontariff barriers. ${ }^{4}$

Finally, trade costs between countries within the European Union have been declining approximately 40 percent faster than trade costs between other countries that belong to the Organization for Economic Cooperation and Development (OECD) (Méjean and Schwellnus 2009). In the event of Brexit, the United Kingdom would not directly benefit from any future reductions in intra-EU trade costs.

In the optimistic soft Brexit scenario, we assume that in the 10 years following Brexit, intra-EU trade costs will fall 20 percent faster than in the rest of the world; while in the hard Brexit scenario, we assume intra-EU trade costs will fall 40 percent faster. This implies that in the soft Brexit case, nontariff barriers within the European Union will fall 5.7 percent during the next decade; while in the hard Brexit case, they will fall 12.8 percent. $^{5}$

Our estimates also account for fiscal transfers between the United Kingdom and the European Union. Like all EU members, the United Kingdom makes a contribution to the EU budget; this net fiscal contribution has been estimated at about 0.53 percent of national income (HM Treasury 2013). One benefit of Brexit for the United Kingdom would be a reduced contribution to the EU budget. But Brexit would not necessarily mean that the United Kingdom would eliminate all contributions to the EU budget. In return for access to the Single Market, EEA members such as Norway make substantial payments to the EU. On a per capita basis, Norway's financial contribution to the European Union is about 83 percent of the U.K. per capita payment (House of Commons Library 2013). Therefore, in

4. These assumptions imply a nontariff barrier increase of 2 percent in the soft Brexit scenario and 6 percent in the hard Brexit scenario. Our data on nontariff barriers between the United States and the European Union are taken from Berden and others (2009).

5. See Dhingra and others (2016a) for a complete explanation of how these changes are calculated. 
Table 1. The Static Effects of Brexit on U.K. Living Standards ${ }^{a}$

\begin{tabular}{lcc}
\hline & Soft Brexit $^{\mathrm{b}}$ & Hard Brexit $^{\mathrm{c}}$ \\
\hline Trade effects & -1.37 & -2.92 \\
Fiscal benefits & 0.09 & 0.31 \\
Total welfare change $^{*}$ & -1.28 & -2.61 \\
Unilateral liberalization $^{\mathrm{d}}$ & 0.30 & 0.32 \\
Total welfare change & -0.98 & -2.29 \\
\hline
\end{tabular}

Source: Dhingra and others (2016a).

a. Units are percent change in per capita income. Results are from simulations of a computable general equilibrium model, as detailed by Dhingra and others (2016a); see specifically their tables A.5 and A.8.

b. Soft Brexit assumes that the United Kingdom could negotiate a deal like Norway's, so tariffs would remain zero. It is assumed that (i) nontariff barriers would increase to one-quarter of the reducible barriers faced by U.S. exporters to the EU (2 percent); (ii) the United Kingdom would not benefit from further integration of the EU, so nontariff barriers will fall 20 percent faster than in the rest of the world (5.7 percent over 10 years); and (iii) the United Kingdom would save 17 percent (the same as Norway) from the fiscal contribution to the EU budget (currently 0.53 percent of GDP), or 0.09 percent of GDP.

c. Hard Brexit assumes that the United Kingdom and the EU impose most-favored-nation tariffs on each other. It is assumed that (i) nontariff barriers would increase to three-quarters of the reducible barriers faced by U.S. exporters to the EU (6 percent); (ii) the United Kingdom would be excluded from further integration of the EU, so nontariff barriers would fall 40 percent faster than in the rest of the world (12.8 percent over 10 years); and (iii) the United Kingdom would save from a large reduction in the fiscal contribution to the EU budget (currently 0.53 percent of GDP) — according to Eurostat, the savings would be about 58 percent, or 0.31 percent of GDP.

d. Unilateral liberalization further assumes that the United Kingdom would impose zero tariffs on all imported goods.

the soft Brexit case we assume that the United Kingdom's contribution to the EU budget will fall by 17 percent (that is, 0.09 percent of GDP).

In the hard Brexit case, where the United Kingdom is outside the EEA, we assume that the United Kingdom will save more of its current contribution. This 0.53 percent saving will include only the public finance components and thus will exclude all the transfers that the European Union makes directly to universities, firms, and other nongovernmental bodies. Under the assumption that post-Brexit the U.K. government will not cut this funding, the saving will be 0.31 percent, according to Eurostat. ${ }^{6}$ This cost will mainly come from the agricultural subsidies in the EU's Common Agricultural Policy.

Table 1 summarizes the results of our analysis. For each case, we calculate the percentage change in the level of income per capita that has the same

6. The data from Eurostat are available at http://ec.europa.eu/budget/figures/2007-2013/ index_en.cfm. Note that we are overstating the benefits of Brexit in the soft Brexit scenario by using the 0.53 percent number; we do not have accurate calculations on the comparable fraction of the 0.31 percent net fiscal contribution for Norway. 
effect on living standards in the United Kingdom as Brexit. ${ }^{7}$ The numbers we report should be interpreted as permanent changes in average income per capita in the United Kingdom that occur immediately following Brexit (relative to the status quo of remaining a full member of the European Union).

In the soft Brexit scenario, there is an overall fall in income of 1.28 percent (a loss of 1.37 percent from trade, plus a lower net fiscal transfer of 0.09 percent) that is driven by current and future changes in nontariff barriers. Nontariff barriers play a particularly important role in restricting trade in services, an area where the United Kingdom is a major exporter. In the hard Brexit scenario, the overall loss increases to 2.61 percent.

Following Brexit, the United Kingdom would no longer be bound by the European Union's common external tariff on imports. Some promarket supporters of the leave campaign have argued that the United Kingdom could benefit by unilaterally removing all tariffs on imports into the United Kingdom in order to lower the cost of imported goods. There seems little political appetite for abolishing all trade protection against China and other emerging economies, but we examine this radical unilateral liberalization policy for completeness. We reran our scenarios after including the additional assumption that the United Kingdom removes all tariffs on imports from anywhere in the world.

We calculate that this would reduce the costs of Brexit by about 0.3 percentage point in both scenarios (row 4 of table 1). But the overall net effect of Brexit (in row 5) remains negative. Part of the reason for this is that WTO tariffs are already quite low, so further reductions do not make a substantial difference. Integration is not simply a matter of lowering tariff rates, but also requires policies such as hammering out regulatory differences in services that rely on international agreements and cannot be achieved unilaterally. ${ }^{8}$

\section{I.B. Brexit's Dynamic Trade Effects}

The estimates given in table 1 are based on a static trade model that does not account for trade's dynamic effects on productivity. Trade can

7. Formally, we calculate the permanent percentage change in income per capita that has the same present discounted value effect on welfare in the United Kingdom as Brexit. We assume an annual discount rate of 4 percent and an intertemporal elasticity of substitution equal to 1 .

8. Economists for Brexit (2016) argue that unilateral liberalization would produce spectacular income gains. Dhingra and others (2016b) show that this comes from making extreme assumptions (such as assuming away all gravity effects in trade, meaning that every nation purchases from the lowest-cost producer in the world regardless of geographical location). 
have positive effects by increasing competition, which reduces excess profits and promotes efficiency. Competition, access to superior intermediate goods, and a larger export market can also stimulate innovation. Recent research finds that dynamic effects may double or triple the size of trade's static effects (Bloom, Draca, and Van Reenen 2016; Bloom and others 2015; Sampson 2016). Unfortunately, there is no canonical quantitative trade model that incorporates these dynamic effects, as the theory is complex and still evolving.

A simple way to evaluate the dynamic consequences of Brexit for trade is to use the results of reduced-form empirical studies of the effects of EU membership. A typical example is that of Scott Baier and others (2008), who find that after controlling for other determinants of bilateral trade, EU members trade substantially more with other EU members than with nonEU members, including members of the EEA and the European Free Trade Association (EFTA) (Switzerland is in the EFTA but not the EEA). Their estimates imply that, if the United Kingdom leaves the EU and joins the EFTA, its trade with countries in the EU will fall by about a quarter.

James Feyrer (2009) uses natural experiments to produce credible estimates of the impact of falls in trade costs on GDP. He finds that a 1 percent decline in trade reduces income per capita by between 0.5 and 0.75 percent. Since about half of U.K. trade is with the European Union, a Brexit-induced trade reduction of 12.5 percent implies that leaving the EU and joining Switzerland in the EFTA would reduce U.K. incomes by between 6.3 and 9.5 percent. These estimates are much higher than the costs obtained from the static trade model given in table 1, suggesting that the dynamic gains from trade may be very important.

Interestingly, these larger long-run effects are in the same ballpark as the benefits that the United Kingdom has gained since 1973 from being part of the European Union. In a recent survey of the evidence of the impact of EU membership, Nicholas Crafts (2016) concludes that EU membership raised U.K. GDP per capita by between 8.6 and 10.6 percent. Ex ante evaluations generally underestimate the benefits of EU membership because they focus on static trade models of the kind portrayed in table 1 .

We have presented a range of estimates, as there is uncertainty over the precise impact of Brexit, and subject the estimates to a wide range of other robustness tests in Dhingra and others (2016a). But the qualitative conclusion that there are nontrivial welfare losses from Brexit-especially from a hard Brexit - are very robust and consistent with a wide range of estimates from other economists using many other modeling assumptions (see, for example, the survey by Emmerson and others 2016). 


\section{I.C. Future Trade Agreements}

Members of the European Union have a common trade policy and are represented by the EU in all international trade negotiations. After Brexit, the United Kingdom will become an independent player, free to seek its own trade deals with the rest of the world. The United Kingdom could use this freedom to look for new trade deals with countries such as China, India, and the United States. Dhingra and others' (2016a) model shows that trade with such non-EU countries does indeed rise after Brexit, as trade diversion falls. But the magnitude of these increases is not nearly enough to offset the decline in trade with the EU. The European Union is the United Kingdom's closest neighbor, and the world's largest market in terms of GDP, so it is difficult to offset the damage from increasing its trade costs vis-à-vis the EU.

When negotiating post-Brexit trade deals, the United Kingdom would not need to compromise with other EU countries as it does now. Conversely, the United Kingdom would need to take on the cost of hiring civil servants to rebuild its capacity to engage in trade negotiations. More important, because Britain's GDP is less than one-fifth of the EU Single Market's GDP, it would have less bargaining power in trade negotiations than the EU does.

The question is whether future trade deals struck by the United Kingdom for access to non-EU markets are going to be much better than the current and future deals the EU strikes. Given the reduction in negotiating power, it seems doubtful.

\section{Foreign Direct Investment}

An important reason for inward FDI to Britain is unfettered access to the EU Single Market, so reduced access will make the United Kingdom a less attractive destination. Studies have usually found that FDI benefits productivity (see Haskel, Pereira, and Slaughter 2007 on U.K. data). Randolph Bruno and others (2016) estimate a gravity model of FDI between 34 OECD countries and find that Brexit would likely lead to a fall in FDI to the United Kingdom by over a fifth. Dhingra and others (2016c) calculate that such a fall would reduce GDP by about 3.4 percent. $^{9}$

9. Since the dynamic reduced form calculation of Feyrer (2009) includes the effects of reduced trade costs on FDI flows, we consider that our estimates of an overall fall of up to 9.5 percent of income already include this FDI effect. 
Financial services constitute about 45 percent of the stock of FDI, and are particularly vulnerable to Brexit. This is because EU membership allows foreign banks to sell ("passport") their services anywhere in the European Union. For example, Switzerland has a comprehensive set of free trade deals with the EU in goods but not in services, which is one reason why Swiss banks set up subsidiaries in the City of London.

\section{Immigration}

A major factor in the Brexit referendum was the desire to reduce immigration. Between 1995 and 2015, the number of EU nationals living in the United Kingdom tripled, mainly after the accession of Poland and other formerly communist countries in 2004. Freedom of movement is a central tenet of the European Union and a quid pro quo of full access to the Single Market. A soft Brexit to a Norway model would also require the continuation of this free movement.

EU migrants are on average better educated, more likely to work, and less likely to claim welfare benefits than the British-born workers (Wadsworth and others 2016). Hence, they have effectively subsidized the public services of U.K. nationals. Further, a detailed analysis of the local labor market impact of these large immigrant flows since 2004 shows no significant fall in jobs or wages for British-born workers, for either the average or less-skilled segments of the distribution. Any negative effects of new waves of immigrants appear to be confined to their closest substitutesolder waves of immigrants (Manacorda, Manning, and Wadsworth 2012).

Indeed, most macroeconomic assessments suggest that immigration, like free trade and FDI, has been a net benefit for the U.K. economy. Hence, reducing immigration after Brexit will do nothing to offset the negative trade and FDI effects of Brexit.

\section{Regulations}

Eurosceptics often point to the promise of better regulations after Brexit. It is important to realize that regulations will not be much affected under the soft Brexit scenario. This is because to access the Single Market, countries like Norway or Switzerland had to adopt the same regulations as the rest of the European Union - but without having a vote on what these regulations are.

Post-Brexit, the United Kingdom could weaken its social, employment, and environmental regulations to some degree. But even if this were politically possible, the country already has some of the most flexible employment 
and product market regulations in the developed world, according to the OECD. ${ }^{10}$ It is unlikely that further weakening its protections (say, to U.S. levels) would make a material difference to its GDP (Springford 2016).

Even if the regulatory costs of EU membership were as high as 0.9 percent of GDP (Crafts 2016), this is still less than half as large as our estimates of the net cost of a hard Brexit, even in the purely static case, and much lower than the 6 to 9 percent costs under the dynamic case. In the United Kingdom, there are many costs of regulation, such as the planning system (Aghion and others 2013), but these problems are primarily homegrown.

\section{Distributional Effects: Did Only the Elites Benefit from EU Membership?}

One view is that the benefits of EU membership accrue overwhelmingly to those with high incomes (the "elites"), whereas those below the lower part of the income distribution lose out. However, when we disaggregate the expected costs of Brexit, the economic pain appears to be evenly distributed across income groups (Breinlich and others 2016). This is unsurprising because the EU consists of richer, highly skilled countries that are more similar to the United Kingdom than the emerging economies of China and India (whose imports could potentially have put downward wage pressure on less-skilled British workers).

Being a member of the European Union helped the United Kingdom reverse a century of relative economic decline. The gap in GDP per capita was reduced significantly with that in the United States, France, and Germany between the last referendum in 1975 and the global financial crisis in 2008 (Aghion and others 2013). Although inequality increased, a difference with the United States is that U.K. median real wages also increased substantially during this period (Belfield and others 2016), and since the early 1990s even those in the bottom 10th percentile have seen improvements. Things changed dramatically after 2007, of course; there were median real wage declines of more than 8 percent through 2014. This certainly fueled anger against elites, but the banking crisis and subsequent austerity can hardly be blamed on the European Union.

10. The United Kingdom ranks second to the United States in terms of product regulation, and third to the United States and Canada in terms of labor regulations. 


\section{Escaping from a Failing Europe}

Another argument heard in favor of Brexit is that the United Kingdom can escape an economically and politically doomed Europe, a "club that no one wants to belong to." One response to this is that through geography alone, Britain is inescapably intertwined with its closest neighbors due to the gravity effects of trade, migration, and foreign investment, regardless of whether it is a member of the EU or not. Furthermore, Europe's economic demise is vastly overblown. GDP per capita growth in the European Union has outstripped that of the United States and Japan since 1991. And forecasts of EU growth over the next decade are similar to (or slightly larger than) those of the United States and Japan. ${ }^{11}$ The problems of slowing growth are shared across the developed world and are not unique to Europe (Gordon 2016).

\section{Why Did People Vote to Leave?}

So why did people vote to leave, despite the economic consensus that this would make them materially worse off? Voting patterns are more a question of political science than economics, but it is worth distinguishing three possible classes of explanations-all of which may be true for different parts of the electorate. First, perhaps people were fully aware of the academic consensus and understood that Brexit would have personal economic costs for them, but they were nevertheless prepared to pay that price for its perceived noneconomic benefits (such as fewer immigrants and greater sovereignty). ${ }^{12}$ This is a perfectly rational trade-off to make in a democracy-one can always choose to reduce rule-based cooperation, cut market trading, and become poorer.

A second explanation also assumes that voters were fully aware of the academic consensus but simply did not believe that there would be any serious economic costs. Indeed, survey evidence suggests that most people thought they would not be economically worse off because of Brexit (Collinson 2016). However, although most voters knew the government's position that there would be economic costs, they seemed less aware of the

11. See, for example, the Conference Board's "Global Economic Outlook" (https://www. conference-board.org/data/globaloutlook/) and "Total Economy Database" (https://www. conference-board.org/data/economydatabase/).

12. Ironically, the United Kingdom will no longer have any vote on the regulations it will still have to obey if it continues to be in the Single Market like Norway, so may arguably end up with less sovereignty under Brexit. 
academic consensus that broadly supported this analysis. ${ }^{13}$ For example, the largest-ever survey of U.K. economists found that 88 percent thought Brexit would be economically damaging, compared with 4 percent who thought there would be benefits, and 8 percent who did not know (Skinner, Gottfried, and Weeks 2016). Many say this does not matter, because all experts are distrusted. Indeed, a leading Brexit campaigner, Michael Gove, who was secretary of state for justice, advised people to ignore the experts and compared the academic critics of Brexit to Nazi scientists persecuting Einstein (Humphries and Rawlinson 2016). Nevertheless, survey evidence collected the week before the referendum showed that academics were trusted on Brexit more than any other group except family and friends (Barrie 2016).

This leaves a third possibility: that many voters were simply unaware there was such a strong academic consensus that Brexit would be economically costly. Social media information often just reinforces prejudices. British newspapers have been overwhelmingly Eurosceptic for decades (Wren-Lewis 2016). And television broadcasters like the BBC stuck to an interpretation of "balance," which meant that every economist who reflected the consensus had to be set against a tiny group of pro-Brexit economists.

It should not be surprising that an academic consensus can remain largely hidden. For example, despite the overwhelming scientific evidence for climate change, many people still doubt its existence. And in an earlier era, this was also true of smoking's harmful effects. Moreover, economics has a much weaker cognitive foundation than the physical and medical sciences on which these findings were based. There are multiple reasons for the Brexit voting patterns, but the lack of knowledge of the academic consensus on the costs is one factor.

\section{Conclusions}

At the time of writing, it appears that the United Kingdom is moving toward the most economically damaging form of a hard Brexit. This seems mainly driven by the desire to impose stronger border controls against EU citizens, something that is difficult to reconcile with membership in the Single Market. Despite the evidence to the contrary, there remains a

13. Indeed, the U.K. Finance Ministry's analysis employed in many ways quite conservative assumptions and was not out of line with consensus forecasts of the economic impact of Brexit (Dhingra and others 2016d). 
prevalent belief—-stoked by populist politicians — that EU immigration has had huge negative effects on workers. This is very similar to the situation in the United States and many other advanced countries, where workers remain frustrated by the slow pace of recovery from the financial crisis.

It is imperative for an informed debate to continue about the likely impact of a hard Brexit on the United Kingdom compared with alternative policies. The populist uprising against globalization risks inflicting the most harm on the very people who are railing most strongly against it.

ACKNOWLEDGMENTS I am grateful for comments from Janice Eberly and participants in the Fall 2016 Brookings Papers conference. This work is based on the excellent endeavors of the "Brexit team" at the London School of Economics' Centre for Economic Performance: Holger Breinlich, Swati Dhingra, Hanwei Huang, Gianmarco Ottaviano, João Pessoa, Thomas Sampson, and Jonathan Wadsworth. Financial support from the Economic and Social Research Council is gratefully acknowledged. This paper reflects events current as of November 25, 2016. 


\section{References}

Aghion, Philippe, Tim Besley, John Browne, Francesco Caselli, Richard Lambert, Rachel Lomax, Chris Pissarides, Nick Stern, and John Van Reenen. 2013. "Investing for Prosperity: Skills, Infrastructure and Innovation." London: London School of Economics, Centre for Economic Performance.

Armstrong, Angus, and Jonathan Portes. 2016. "Commentary: The Economic Consequences of Leaving the EU." National Institute Economic Review 236: 2-6.

Baier, Scott L., Jeffrey H. Bergstrand, Peter Egger, and Patrick A. McLaughlin. 2008. "Do Economic Integration Agreements Actually Work? Issues in Understanding the Causes and Consequences of the Growth of Regionalism." World Economy 31, no. 4: 461-97.

Barrie, Josh. 2016. "These Are the Groups People Trust and Don't Trust on the Brexit Debate.” Indy100 (The Independent), May 20. https://www.indy100.com/ article/these-are-the-groups-people-trust-and-dont-trust-on-the-brexit-debate-ZkxJoirAczb

Belfield, Chris, Jonathan Cribb, Andrew Hood, and Robert Joyce. 2016. "Living Standards, Poverty and Inequality in the UK: 2016." Report no. 117. London: Institute for Fiscal Studies.

Berden, Koen G., Joseph Francois, Saara Tamminen, Martin Thelle, and Paul Wymenga. 2009. "Non-Tariff Measures in EU-US Trade and Investment: An Economic Analysis." Report no. OJ 2007/S180-219493. Rotterdam: Ecorys.

Bloom, Nicholas. 2014. "Fluctuations in Uncertainty." Journal of Economic Perspectives 28, no. 2: 153-76.

Bloom, Nicholas, Mirko Draca, and John Van Reenen. 2016. "Trade Induced Technical Change? The Impact of Chinese Imports on Innovation, IT and Productivity." Review of Economic Studies 83, no. 1: 87-117

Bloom, Nicholas, Paul M. Romer, Stephen J. Terry, and John Van Reenen. 2015. "Trapped Factors and China's Impact on Global Growth." Discussion Paper no. 1261. London: London School of Economics, Centre for Economic Performance.

Breinlich, Holger, Swati Dhingra, Thomas Sampson, and John Van Reenen. 2016. "Who Bears the Pain? How the Costs of Brexit Would Be Distributed across Income Groups.” Brexit Analysis no. 7. London: London School of Economics, Centre for Economic Performance.

Bruno, Randolph, Nauro Campos, Saul Estrin, and Meng Tian. 2016. "Gravitating Towards Europe: An Econometric Analysis of the FDI Effects of EU Membership." Brexit Analysis no. 3 (technical paper). London: London School of Economics, Centre for Economic Performance.

Campos, Nauro F., Fabrizio Coricelli, and Luigi Moretti. 2015. "Norwegian Rhapsody? The Political Economy Benefits of Regional Integration.” Discussion Paper no. 10653. London: Centre for Economic Policy Research.

Collinson, Patrick. 2016. "Brexit: Two-Thirds Foresee No Negative Impact on Their Finances." The Guardian, June 1. 
Costinot, Arnaud, and Andrés Rodríguez-Clare. 2014. "Trade Theory with Numbers: Quantifying the Consequences of Globalization." In Handbook of International Economics, Volume 4, edited by Gita Gopinath, Elhanan Helpman, and Kenneth Rogoff. Amsterdam: North-Holland.

Crafts, Nicholas. 2016. "The Growth Effects of EU Membership for the UK: A Review of the Evidence." Working Paper no. 280. Coventry: University of Warwick, Centre for Competitive Advantage in the Global Economy.

Dhingra, Swati, Hanwei Huang, Gianmarco Ottaviano, João Paulo Pessoa, Thomas Sampson, and John Van Reenen. 2016a. "The Costs and Benefits of Leaving the EU: Trade Effects.” Brexit Analysis no. 2 (technical paper). London: London School of Economics, Centre for Economic Performance.

Dhingra, Swati, Gianmarco Ottaviano, Thomas Sampson, and John Van Reenen. 2016b. "Economists for Brexit: A Critique." Brexit Analysis no. 6. London: London School of Economics, Centre for Economic Performance.

2016c. "The Impact of Brexit on Foreign Investment in the UK." Brexit Analysis no. 3. London: London School of Economics, Centre for Economic Performance.

_ 2016d. "The UK Treasury Analysis of 'The Long-Term Economic Impact of EU Membership and the Alternatives': CEP Commentary.” Brexit Analysis no. 4. London: London School of Economics, Centre for Economic Performance.

Economists for Brexit. 2016. “The Economy after Brexit.” http://www.economists forbrexit.co.uk/publications

Emmerson, Carl, Paul Johnson, Ian Mitchell, and David Phillips. 2016. "Brexit and the UK's Public Finances.” Report no. 116. London: Institute for Fiscal Studies.

Feyrer, James. 2009. "Trade and Income: Exploiting Time Series in Geography." Working Paper no. 14910. Cambridge, Mass.: National Bureau of Economic Research.

Gordon, Robert J. 2016. The Rise and Fall of American Growth: The U.S. Standard of Living since the Civil War. Princeton University Press.

Handley, Kyle, and Nuno Limão. 2015. "Trade and Investment under Policy Uncertainty: Theory and Firm Evidence." American Economic Journal: Economic Policy 7, no. 4: 189-222.

Haskel, Jonathan E., Sonia C. Pereira, and Matthew J. Slaughter. 2007. "Does Inward Foreign Direct Investment Boost the Productivity of Domestic Firms?" Review of Economics and Statistics 89, no. 3: 482-96.

HM Treasury. 2013. "European Union Finances 2013: Statement on the 2013 EU Budget and Measures to Counter Fraud and Financial Mismanagement." Cm no. 8740. London.

House of Commons Library. 2013. "Leaving the EU." Research Paper no. 13/42. London.

Humphries, Will, and Kevin Rawlinson. 2016. "Gove's Nazi Jibe at Pro-EU Experts." The Times, June 22.

Manacorda, Marco, Alan Manning, and Jonathan Wadsworth. 2012. "The Impact of Immigration on the Structure of Wages: Theory and Evidence from Britain." Journal of the European Economic Association 10, no. 1: 120-51. 
Méjean, Isabelle, and Cyrille Schwellnus. 2009. "Price Convergence in the European Union: Within Firms or Composition of Firms?" Journal of International Economics 78, no. 1: 1-10.

Office for National Statistics. 2015. "How Important Is the European Union to UK Trade and Investment?" Newport, Wales: UK Statistics Authority.

Sampson, Thomas. 2016. "Dynamic Selection: An Idea Flows Theory of Entry, Trade, and Growth." Quarterly Journal of Economics 131, no. 1: 315-80.

Skinner, Gideon, Glenn Gottfried, and Tom Weeks. 2016. "Economists' Views on Brexit." Poll, May 28. London: Ipsos MORI.

Springford, John. 2016. "Brexit and EU Regulation: A Bonfire of the Vanities?" Policy Brief. London: Centre for European Reform.

Wadsworth, Jonathan, Swati Dhingra, Gianmarco Ottaviano, and John Van Reenen. 2016. "Brexit and the Impact of Immigration on the UK." Brexit Analysis no. 5. London: London School of Economics, Centre for Economic Performance.

Wren-Lewis, Simon. 2016. "The Media and Brexit Redux." mainly macro blog, June 3. 